\title{
American Immigration Policy: The 1965 Act and its Consequences
}

\author{
By \\ Timothy J. Hatton \\ (Australian National University and University of Essex)
}

November 2012

\begin{abstract}
The 1965 Amendments to the Immigration and Nationality Act introduced radical changes to US immigration policy. It abolished the country of origin quotas which had been in place since the 1920s and it made family reunification the principal criterion for admission. This legislative change was followed by a steep upward trend in total immigration and by a dramatic shift in the source country composition away from Europe and towards Asia and Latin America. Yet this was not what those who framed the legislation expected, and the results are seen by most observers as unintended consequences. This paper asks if and how the 1965 Act transformed American immigration. The results were partly due to the preexisting legislation and partly to the admission of immigrants outside the terms of the Act. But much of it was due to the Act itself, and specifically to the pattern of chain migration that followed from it. Econometric estimates indicate that the poorer the source country, the greater the effect of the existing stock of immigrants on the subsequent inflow from that source.
\end{abstract}

JEL Codes: F22, J15, J61, N32.

Keywords: Immigration Policy; Immigration Multiplier.

Acknowledgements: I am grateful for useful comments from John Tang and to participants at the $3^{\text {rd }}$ TEMPO Conference in International Migration at Nuremberg. 


\section{Introduction}

The 1965 Amendments to the Immigration Act are often seen as a decisive break in American immigration policy and one with far reaching consequences. The most important change was to replace the national origins quotas, which heavily favoured British, German and Irish immigrants, with a less discriminatory system. Named after its sponsors, the HartCeller Act amended the 1952 Immigration and Nationality (McCarran-Walter) Act, which had largely reaffirmed the national origins system that had been in place since the early 1920s. Thirteen years later, against the background of the civil rights movement and with a sweeping victory for the Democrats in the 1964 election, this system was finally overturned and the United States opened its doors to immigrants from all over the world. The decades following its enactment saw a dramatic rise in the total number of immigrants and an equally dramatic switch in the source country composition away from Europe towards Asia and Latin America. To many observers the 1965 Act was a defining moment that radically transformed American immigration and provided the foundation for all that followed.

Yet in some respects the 1965 Act was a modest reform--at least in the minds of contemporary legislators. Thus President Lyndon B. Johnson signed it into law with the following remark: "This bill that we will sign today is not a revolutionary bill. It does not affect the lives of millions. It will not reshape the structure of our daily lives, or really add importantly to either our wealth or our power." ${ }^{1}$ For him the Act was a symbolic rather than a substantive reform. Similarly, Senator Edward Kennedy (D-MA), one of the Act's main advocates commented in the early stages of its progress through Congress that: "The bill will not flood our cities with immigrants. It will not upset the ethnic mix of our society. It will not relax the standards of admission. It will not cause American workers to lose their jobs." ${ }^{2}$ Of course comments such as these may simply have been designed to reassure anxious constituents and assure the bill a smooth passage through both houses.

Although not all contemporaries were as sanguine as this, historians have generally taken the view that the legislators in 1965 genuinely believed that the increase in immigrant numbers would be moderate and that shifts in the source country composition would be gradual. According to David Reimers (1983, p. 10) "Congress did not intend to make radical changes in immigration patterns when it amended the McCarran-Walter Act, nor did the lawmakers mean to increase immigration substantially." Roger Daniels (2004, p. 135), remarks that: "Since the new law so resembled the old, it is not surprising that few observers, if any, expected major change to result." He goes on to comment that: "Clearly the 1965 law has not worked in a way that either its proponents or its opponents

\footnotetext{
${ }^{1}$ President Johnson's remarks at the signing of the immigration bill, Liberty Island, New York, October 3, 1965, from LBJ archive at: http://www.lbjlib.utexas.edu/johnson/archives.hom/speeches.hom/651003.asp.

${ }^{2}$ U.S. Senate, Subcommittee on Immigration and Naturalization of the Committee on the Judiciary, Feb. 10, 1965. pp. 1-3, quoted in Centre for Immigration studies (1995).
} 
expected" (2004, p. 139). Similarly, Aristide Zollberg comments that: "while the lawmakers did intend to eliminate the immigration system's discriminatory features, notably as they affected Asians and West Indians, they did not anticipate that incoming flows would expand as much as they did, nor that non-European sources would become as dominant (2006, p. 337-8). ${ }^{3}$

The ensuing changes in the scale and structure of immigration have provoked controversy. There has been an ongoing debate about the impact of the forty-year surge in immigration on the employment and earnings of low-skilled native-born workers. Some economists have also argued that that the low relative earnings of immigrants, their slow assimilation, and increasing welfare dependence in the 1970s and 1980s was a direct consequence of the compositional shifts set in train by the 1965 Act (Briggs, 1984; Smith and Edmonston, 1997; Borjas, 1999; Hanson, 2005). Others have pointed to the wider social and cultural effects, both positive and negative, of increasing ethnic diversity (Alba and Nee, 2003; Huntington, 2004; Bean and Stevens, 2003; Rumbaut and Portes, 2006). To quote one of these "the Immigration Act of 1965 has probably had, in the long run, an impact on American society as deep as the initially more acclaimed civil rights laws of the decade" (Alba and Nee, 2003, p. 174). While much attention has been paid to the putative effects of the 1965 reforms, much less attention has been given to exactly how, and through what mechanisms, the 1965 Act changed the face of United States immigration.

So what did the 1965 Act actually do and how did it shape the subsequent patterns of immigration? In this paper I first examine how the 1965 Act differed from the pre-existing legislation, and how its provisions were influenced by the political background and the contemporary debate in Congress. I then explain how the new regime functioned. I argue that some of the trends attributed to the 1965 Act, in fact predated it, and that, to a considerable extent, they were due to other policy initiatives. These interacted with the Act's provisions to change the scale and structure of immigration in a way that its original architects had not envisaged. I then explore the key mechanism involved, the so-called immigration multiplier. Econometric estimates show that the effect of the existing migrant stock on the subsequent flow of immigrants is substantially larger the poorer is the source country. These findings are drawn together in the concluding section.

\section{The 1965 Amendments to the Immigration Act.}

The Acts of 1952 and 1965

In order to appreciate what the 1965 Act did it is necessary first to compare it with the preexisting legislation--the McCarran Walter Act (effective December 24, 1952). The 1952 Act

\footnotetext{
${ }^{3}$ An often recurring phrase in the literature relating to effects of the 1965 Act is "unintended consequences" (Lee, 1998, p. 49; Smith and Edmonston, 1997, p. 28; Alba and Nee, 2003, p. 176; Reimers, 1983 (in the title); Briggs 2003, p.133).
} 
had reaffirmed the national origins quota system introduced in the Johnson-Reed Act of 1924, which itself replaced the emergency quota of 1921. As in the 1924 Act, country quotas were set, based on the ancestry of the American population in 1920. Under the 1952 Act 81.6 percent of the total numerical quota was assigned to Western European countries, principally the UK (43.2\%) Germany (16.7\%) and Ireland (11.5\%), with 16 percent allocated to countries in Southern and Eastern Europe. Unused quota could not be transferred from one source-country to another. The Act also introduced a system of preferences, one for employment-based immigrants and three for relatives (Table 2) while, as previously, spouses and children of US citizens were admitted outside the quota. Perhaps most important, the McCarran-Walter Act eased the pre-existing legislation by introducing a small quota for immigration from the so-called Asia-Pacific Triangle (2000 in total) and by allowing Asians already in the United States to naturalize. As in the pre-existing legislation no limit was placed on immigrants with roots in the Western Hemisphere and the Act changed to non-quota status immigrants from source countries in Central and South America that had become independent. On the other hand it restricted immigration from Caribbean colonies by removing the provision that these immigrants could be charged against the quota of the governing country (notably the UK).

The 1965 Hart-Celler Act (effective $1^{\text {st }}$ July 1968) represented a distinct break with the past. ${ }^{4}$ The most important change was the abolition of the country quotas based on the national origins formula. Instead there was an overall limit of 170,000 for the Eastern Hemisphere with a cap of 20,000 for those born in any individual country and its colonies. The Asia Pacific triangle was scrapped and the countries that comprised it were included under the Eastern Hemisphere quota. And, since it was now a hemispheric pool, the transfer of unused quota was no longer an issue. ${ }^{5}$ The preference system was reorganised under eight preferences, as compared with the previous five (Table 2). Four of these were classes of non-immediate relatives, two were based on skill or occupation, and one brought refugees formally into the preferences system. As in earlier legislation, immediate relatives (spouses and children) were exempt from the numerical limit, although this was now extended to include the parents of US citizens. A major change was the introduction of an overall quota of 120,000 for the Western Hemisphere, which had not previously been subject to a quota, but without an individual country cap. ${ }^{6}$ No system of preferences was applied to the Western Hemisphere until 1976, and the two hemispheres were merged into a worldwide numerical limit of 290,000 in 1978.

\section{Politics and interest groups}

\footnotetext{
${ }^{4}$ Even though, strictly speaking it was a set of amendments to the 1952 Act.

${ }^{5}$ Between December 1965 and July $1^{\text {st }} 1968$ when the Act came into force, arrangements were made for the transfer of unused country quotas to an immigration pool up to the limit of 170,000 .

${ }^{6}$ The Act set up a Select Commission on Western Hemisphere Immigration to recommend a framework for Western Hemisphere immigration. In the absence of recommendations to the contrary, the cap took effect in 1968.
} 
There are a number of reasons for the shift in immigration policy between 1952 and 1965. Clearly the political climate had changed in the intervening years. But it was not simply due to the change of the party in power. While Presidents Kennedy and Johnson supported reform of the quota system, so did their predecessors, Presidents Truman and Eisenhower. Indeed the 1952 Act had been passed on an override of President Truman's veto. ${ }^{7}$ Neither was it due simply to the Democrats' enhanced strength in Congress following their overwhelming victory in the 1964 election, although that undoubtedly helped. ${ }^{8}$ The 1965 Act received overwhelming support from both parties in both houses whereas a majority of both parties had voted for the override in 1952. However, there were important changes in the influential committee members of both the House of Representatives and the Senate (Tichenor, 2002, Ch7, Stern, 1975, pp. 67-71, ). In the Senate, the subcommittee that considered the 1965 Bill was chaired by Edward Kennedy (D-MA), and it included Hiram Fong (R-HI), the first Asian-American elected to the Senate. In the House, the subcommittee was chaired by Michael Feighan (D-OH), who replaced Francis Walter (D-PA), one of the architects of the 1952 Act and a lifelong restrictionist, who died in 1963. The Chair of the House Judiciary Committee in 1965 was Emanuel Celler (D-NY), who had voted against the override in 1952.

The wider political environment changed radically between 1952 and 1965. In 1952 the vote for the McCarran-Walter Act took place against the background of McCarthyism and a widespread distrust of foreigners. Indeed, McCarran (D-NV) sponsored the Internal Security Act and, as chairman Senate Judiciary Committee, created the Senate Internal Security Subcommittee that investigated subversion in the Federal Government. Francis Walter, also a staunch anti-communist, had previously chaired the House Committee on Un-American Activities. Thus the McCarran-Walter Act (Section 212 (a)) included a long list of exclusions for communists and others who were thought to be prejudicial to the national interest. By contrast, the background to the 1965 Act was the movement that led to the Civil Rights Act of 1964, even though the Cold War was still at its height. Both the civil rights reforms and immigration reforms were proposed by President Kennedy and were seen by many as encompassing the same principle of non-discrimination (Briggs, 1998, p. 122). ${ }^{9}$

Kennedy's original bill, introduced in 1963, proposed that national origins quotas would be abolished (including the restrictions on the Asia-Pacific Triangle) and replaced by a system of

\footnotetext{
${ }^{7}$ Each of these presidents proposed or supported radical reforms: Truman in 1952, Eisenhower in 1956 and 1960, Kennedy in 1963, and Johnson in 1964. Interestingly, Johnson voted for the override in 1952.

${ }^{8}$ One particular way in which it helped was that, with a Democrat majority in the House of 295 to only 140 Republicans, the eastern and northern Democrats did not have to depend on their colleagues from the south. Although a majority of southern Democrats voted against the bill in August 1965, of the 48 Democrats who replaced Republicans in the 1964 election 47 voted in favor (Stern, 1975, pp. 56, 58, 128).

${ }^{9}$ In the years since the 1952 Act there had been many attempts to reform or amend the national origins system but none had been successful. The proposals included pooling unused quota and altering the base year for the national origins formula. In 1962 a bill sponsored by Philip Hart (D-MI), who subsequently introduced the 1963 Administration Bill in the Senate, proposed a formula based on the pattern of immigration in the last 15 years adjusted by the population of source countries.
} 
preferences, with a cap of 10 percent for any single country. Under this system, the first preference, up to 50 percent of the quota, would be allocated to highly skilled or trained workers, with subsequent preferences for occupations in demand, non-immediate relatives, and refugees. ${ }^{10}$ Although the Administration Bill did not reach the floor of the House or the Senate, essentially the same proposals were put forward after Kennedy's death by President Johnson. But what emerged after the committee stages was rather different. The balance of preferences was shifted towards family reunification and away from employment and skills. In the 1965 Act the occupation-based preferences were third and sixth, each up to a maximum of ten percent of the overall Eastern Hemisphere total, with the first, second, fourth and fifth preferences allocated to family reunification. As Table 2 illustrates, the employment based preferences were demoted in the order and their share reduced from 50 to 20 percent. In addition it required that admission under the third, sixth and nonpreference category, as well as non-immediate relatives from the Western Hemisphere, required certification from the Secretary of Labor that there were not sufficient able and qualified workers available and that it would not adversely affect wages.

The modifications to the original Administration Bill were seen as necessary to gain majority support in both houses. When defending the Bill before the House, Emanuel Celler argued a number of key points:

The thrust of this bill is no appreciable increase in numbers. . . . With the end of discrimination due to place of birth, there will be shifts to countries other than those of northern and western Europe. Immigrants from Asia and Africa will have to compete and qualify in order to get in, quantitatively and qualitatively, which, itself will hold the numbers down. There will not be, comparatively, many Asians or Africans entering this country. . . .since the people of Africa and Asia have very few relatives here, comparatively few could immigrate from those countries because they have no family ties in the United States. . .. no one can come without the individual certificate from the Secretary of Labor guaranteeing that the American workman will not be displaced. . . . few of them can even pay the cost of the ticket to come here. There is no danger whatsoever of an influx from the countries of Africa and Asia (Congressional Record, Aug. 25, 1965, p. 21757-8).

Thus there were two main reasons for thinking that the pattern of immigration would change only slowly. The first was the notion that relatively few potential immigrants from the poorer parts of the world would qualify under the employment preferences. The second was that the weight given to family preferences would ensure that the existing pattern of migration would be replicated through chain migration. The first of these was

\footnotetext{
${ }^{10}$ The Bill, H.R. 7700, provided for the abolition of national origins to be phased in over five years and it proposed to extend non-quota status to Western Hemisphere countries becoming independent since the McCarran-Walter Act. It would also have given authority to the president to reserve a large part of the pool for country-specific 'national security provision' and for refugees. The same proposals were published posthumously in the revised edition of John F. Kennedy's book A Nation of Immigrants (1964, Appendix D, pp. 102-7).
} 
used to garner support from organised labor, particularly the AFL-CIO, which came out in support of the Act (Stern, 1975, pp. 107-110, 186-191; Tichenor, 2002, pp. 203-11). Under the McCarran Walter Act, the burden of proof lay with Secretary of Labor to show cause to deny entry. Now the burden of proof lay with applicants, and often also their prospective employers, to show no adverse consequences. Effectively this meant that an applicant either had to be qualified in one of a selective list of occupations, or required a job offer prior to admission. This was seen as a much tougher labor test and one that would most affect prospective immigrants from the Western Hemisphere (Schwartz, 1966, pp. 99-102; Keely 1971, p. 160).

Perhaps more important was the stress on family reunification. Tight restrictions against Asian immigrants had been in place since the 1882 Chinese Exclusion Act and there were concerns in some quarters about a steep rise in Asian immigration. Responding to these, Attorney General Robert Kennedy informed the House Immigration Subcommittee that immigration from the Asia-pacific Triangle would be about 5000 in the first year and would subsequently decline (U.S. Congress, House Committee on the Judiciary, Subcommittee No 1, 1964 Hearings, p. 418.). While some observers have warned against taking such comments at face value (Chin, 1996), others in authority took a similar, if less extreme, view. Thus Senator Hiram Fong argued that the base population of Asian origin was so small that people with Asian roots could never amount to more than 1 percent of the population (U.S. Senate, Subcommittee on Immigration and Naturalization of the Committee on the Judiciary, Washington, D.C., Feb. 10, 1965, pp.71, 119.). The same point was put by the Japanese-American Citizens' League (Briggs 1984, p. 69), but their arguments for a 'fairer' policy came to nothing. In large part this is because there was powerful support for the notion that, through the same mechanism, the policy would favor mainly southern and eastern Europeans. ${ }^{11}$ These had been a large share of immigration in the two decades before 1914, but had received only small quotas under the national origins system. Nevertheless, in 1960 they still constituted 40 percent of the migrant stock and therefore stood to benefit significantly from a policy based on family reunification.

In fact most of the debate in Congress was about immigrants from the Western Hemisphere. The original bill placed no ceiling on Western Hemisphere immigrants. But concerns about cheap labour from across the Mexican border led in 1964 to the termination of the Bracero program, which had, since the early 1940s, brought in temporary workers for seasonal employment on southern farms. ${ }^{12}$ Some lobbyists sought to restrict what they

\footnotetext{
${ }^{11}$ Some of the key legislators, such as Feighan, represented districts that were dominated by immigrants from southern and Eastern Europe. These included House sub-committee members Harold Donahue (D-MA), Jacob Gilbert (D-NY) and Peter Rodino (D-NJ) (Stern 1975, pp. 40, 69-70).

${ }^{12}$ Some 4.5 million workers came under the Bracero Program between 1942 and 1964, 93 percent of whom were Mexicans. Reaction against illegal Mexicans resulted in Operation Wetback which was mounted in 1954, removing over a million in that year.
} 
thought might be a surge of immigrants from the south by imposing an overall cap on Western Hemisphere immigration. This was proposed in the House by Clark MacGregor (R$\mathrm{MN}$ ) and was defeated by a narrow margin. It was reintroduced in the Senate and became part of the final bill, such that in the absence of further amendments it was imposed in 1968. As noted earlier a system of preferences was introduced for the Western Hemisphere in 1976 and the two Hemispheres were merged in 1978. With the exception of specific measures for refugees in 1980, and illegal immigrants in 1986, this basic structure remained in place until it was superseded by the 1990 Immigration Act (effective 1992).

\section{The changing pattern of immigration}

\section{Trends in immigration}

In assessing the effects of the Hart-Celler Act it is useful to begin with a longer term perspective. As Table 1 illustrates, the pattern of immigration was changing even before the 1965 Act came into force in mid-1968. Clearly it cannot have been initiated by the HartCeller Act. In the 1950s the total volume of immigration rose sharply from the levels of the 1930 s and 1940s. From the 1950 s to the 1960 s there was a sharp rise in Asian immigration; starting from a small base in 1951 the number increased by a factor of six by 1965 . This was partly due to the modest quota that replaced the total ban on immigration from the Asia Pacific Triangle. And it was fuelled by the fact that Asians could now become citizens and therefore bring in close relatives as non-quota immigrants. There is also a notable increase across these decades in immigration from the Caribbean (mainly Cubans) and from South America--at a time when there was no cap on Western Hemisphere immigration.

Figure 1 shows the persistent upward trend in the annual number of immigrants admitted during the life of the McCarran-Walter and Hart-Celler Acts, from less than 200,000 to more than 600,000 per annum. During the period from 1952 to 1965, when unused quota could not be transferred, the number admitted under the quota was only about two thirds of the numerical limit (154,657). In the transitional period, from 1965 until 1968, when unused quota was made transferable, the numbers rose and then jumped to the new quota level in 1968. Non-quota immigration gradually increased under the McCarran Walter Act, such that between 1953 and 1965 only 35 percent of immigrants were admitted under the quota. In 1968 non-quota immigration fell sharply as the numerical limit was expanded to include the Western Hemisphere. From 1969 numerically exempt immigration again increased, with a jump when the worldwide limit was introduced, and by the early 1980s it exceeded quota immigration. One implication stemming from Figure 1 (and Table 1) is that the trends in the volume and composition of immigration are due in large measure to the growth in the number of immigrants admitted outside of the numerical limit.

One important feature, reflected in Table 1, is the treatment of Western Hemisphere immigrants. The number of Mexicans increased sharply in the 1950s, from around 7,000 per year before 1952 to 40,000 in 1965. These figures exclude Braceros who were temporary 
workers, although there was some spillover from the Bracero Program to permanent residency. And although there was no cap on the Western Hemisphere, visas were restricted by US consular offices in Mexico and elsewhere in Latin America on the grounds that prospective immigrants would not qualify for labor certification or because of the likelihood that they would become a public charge (Schwartz 1966, pp. 102-3; North and Houstoun, 1979, p. 37). The new law seems to have operated differently and, in the absence of the Bracero Program, Mexicans and also other Latin Americans increasingly gained admission. One method was first to work illegally and then to acquire the support of an employer in order to apply for certification, which was required for low skilled labor. ${ }^{13}$ But a larger share came through family reunification, which had previously been restricted only to immediate family members.

\section{Refugees}

An important but sometimes neglected stream of immigration in the first three post-war decades is refugees. Under the McCarran-Walter Act there was no formal refugee stream but refugees were admitted under a clause that gave the Attorney General parole authority to admit refugees. ${ }^{14}$ Some were admitted under special legislation, largely for displaced persons and Cold War refugees. As Table 2 shows, in the 1950s and 1960s the overwhelming majority came from Europe-mainly the residue of World War II displacements, followed by a stream Soviet dissidents and refugees from the Hungarian uprising. But from the early 1960s the balance changed, first towards the Caribbean with the Cuban exiles, and then in the 1970s with a surge of refugees from Vietnam, Laos and Cambodia. ${ }^{15}$ This was one important element in the shifting source country composition. And it was compounded by the fact that these new refugees could more readily unite with their relatives than could escapees from behind the Iron Curtain.

By providing a specific preference for refugees in the 1965 Act, Congress had sought to limit the power of the executive to admit refugees. But such hopes were quickly dashed. On the same day that the Hart-Celler Act passed into law ( $3^{\text {rd }}$ October) President Johnson also signed the Refugee Conditional Entrants Act, under which 140,000 refugees were admitted in the years up to 1980. Indeed, it was the continuing practice of ad hoc refugee admissions outside of the numerical limit that led to the 1980 Refugee Act (Kennedy 1981; Anker and

\footnotetext{
${ }^{13}$ A letter from the prospective employer was required stating that there were no Americans who were "able, willing, qualified, and available" and that the normal wage for the job would be paid. Mexicans often entered with non-immigrant visas, with a border crossing card (I-186), or without inspection, and then worked illegally. The illegal immigrant then applied with the employer's support for labor certification, returning home once the visa arrived in order to re-enter as a permanent resident (North and Houstoun, 1979, pp. 43-5).

${ }^{14}$ This was under section 212 (d) (5) of the McCarran-Walter Act. Those admitted by parole authority did not initially gain permanent residency but most were subsequently adjusted. Refugee policy, and particularly the use of parole, is described in detail by Anker and Posner (1981-2).

${ }^{15}$ Kraly (1990, pp. 86-9) gives a detailed analysis of refugees granted permanent resident status by period and country of origin.
} 
Posner 1981-2). ${ }^{16}$ This introduced a separate refugee stream (initially of 50,000 places), eliminating the $7^{\text {th }}$ preference, and reducing the numerical limit to 270,000 . Ironically, within a matter of weeks the Cuban exodus erupted and parole authority was invoked once again to cope with those fleeing in what became known as the Mariel Boatlift. ${ }^{17}$ Exceptions continued to be made but, more importantly, year-by-year allocations were made far in excess of 50,000, so that in the two decades from 1980 nearly 1.7 million refugees were admitted under the 1980 Act.

Apart from refugees, a number of other special exemptions were made-both before and after the 1965 Act came into force. Although the numbers were relatively small compared with refugees, they included administrative waivers of exclusion, adjustments of a status and suspensions of deportation as well as specific programs for orphans and disaster victims (Bennett, 1966; ).

\section{Immigration by class of admission}

The composition of entry routes by source region is illustrated in the upper panel of Table 4 for fiscal year 1982. Three features stand out. The first is that two thirds of all immigrants were admitted either through the family preferences or as immediate relatives. For immigrants from North and South America the share was more than ninety percent. Second, other admissions, made up mainly of refugees, account for more than a quarter of the total. For Asians the share exceeded 40 percent and it was the single largest contributor to the rapid growth of the immigrant population. For Asians and for those from some parts of Europe, this was important to establishing the base for further immigration through family reunification. Third, because more than half of all immigrants were admitted outside the quota, employment-based admissions account for less than five percent of the total. It is worth noting that this category includes accompanying relatives as well as the principals. As a result, just two thirds of the 4.4 percent were immigrants admitted directly on the basis of employment.

The lower panel of Table 4 shows that, of all immigrants aged 16 and over, 5.4 percent were admitted with labor certification. Clearly, the certification did not screen out immigrants from Asia and Latin America, as had been expected in 1965, although the rates were lower than for immigrants from Europe. However, more than two-fifths of adults declared an

\footnotetext{
${ }^{16}$ In 1968 the United States acceded to the 1967 Protocol to the Refugee Convention of 1951 (thereby invoking the terms of the Convention) but this was not formally incorporated into law until the 1980 Act. The terms of the Convention include the definition of a refugee (Article 1) as someone with a 'well founded fear of persecution ...' (rather than just those fleeing communism) and the so-called non-refoulement clause (Article 33) prohibiting that a person be returned to a place where his or her life or freedom would be threatened.

${ }^{17}$ In April 1980, after a group of dissidents gate-crashed the Peruvian Embassy in Havana, Fidel Castro announced that any Cubans who wanted to leave could depart through the port of Mariel. Between then and October 1980, approximately 125,000 Cubans sailed for the United States, most of whom settled in Miami.
} 
occupation and these were listed according to a standard occupational classification. ${ }^{18}$ These occupations have been divided into two broad categories. The skilled group includes professional technical and managerial as well as clerical and skilled blue collar workers, and the unskilled group is mainly labourers, farm-hands and domestic workers. Of all those reporting an occupation 57 percent were skilled, as compared with 65 percent in the last years of the McCarran-Walter Act (Mott, 1966, p. 25). The labor certification system was heavily criticised for being administratively cumbersome and not particularly skill-selective, especially in relation to labor migrants from the Western Hemisphere. ${ }^{19}$ Table 4 shows that, on this classification, 86 percent of those with labor certification were skilled. The last row of the table shows that, among those declaring an occupation, but without certification, the share of skilled was much lower at 54 percent. Thus the labor certification program was somewhat skill selective, and it is possible that rapidly improving skills and education allowed immigrants from the poorer parts of the world to take advantage of this route.

The inflow also included an unknown number of illegal immigrants. It is estimated that the stock of undocumented stood at around three million in 1980 most of whom had arrived during the previous decade 1960s. Nearly four fifths were from North and South America, with more than half from Mexico alone (Warren and Passel, 1987, p. 380). While adding to the total number of arrivals these do not appear in the statistics for legal immigration except insofar as initially undocumented immigrants were able to find a way to become legalised. The total rose strongly in the 1980s and then declined as 2.7 million were legalised under the Immigration Reform and Control Act (IRCA) of 1986 (Passel, 2007). Those who were legalised qualified for family reunification, which added to the volume of visa applications during the 1990s (Woodrow-Lafield, 1994).

\section{The power of chain migration}

\section{The immigration multiplier}

Chain migration is widely seen as a powerful force that magnifies the effects of original arrivals leading to strong persistence in immigration streams from specific source countries and localities. To many observers the Hart-Celler Act, with its emphasis on family preferences and with immediate family members exempt from numerical limitation, firmly enshrined chain migration as the principal entry channel. As we have seen, some observers thought that this, together with strict labor certification, would ensure that the source country composition of immigration would change only slowly. Yet shifts in the composition occurred more rapidly than most would have expected. Here I examine the strength of the relationship between the stock of immigrants and the subsequent flow in the decades following the 1965 Act.

\footnotetext{
${ }^{18}$ This was the intended occupation for those with certification and the previous occupation for those without.

${ }^{19}$ The legal issues involved are discussed by Rubin and Mancini (1976-7) and Steele (1981-2).
} 
A number of studies have examined the 'immigration multiplier' for this period. Jasso and Rosenzweig (1986, 1989, 1990) used microdata from the early 1970s to calculate sponsorship rates through the different immigration channels, which could then be aggregated to produce immigration multipliers. They concluded that, on average, one original male entering as a labor certified immigrant would produce 0.9 additional immigrants over the following decade and a total of 1.2 additional migrants over three generations. Sponsorship rates for females were slightly higher, and for the spouses of labor certified immigrants substantially lower (Jasso and Rosenzweig, 1990, pp. 218-221). They also found that four fifths of those who sponsored spouses were native-born US citizens and thus were not linked to a previous immigrant. The top five countries for sponsored spouses were either contiguous with the US (Canada and Mexico) or locations of major military bases (Philippines, Germany and the UK). Thus for these reasons, the immigration multiplier as calculated through sponsorship rates does not seem to have been as strong as some would believe.

More recently Yu (2008) calculated synthetic sponsorship rates from the different categories of admission for each year from 1972 to 1997 taking into account accompanying family as well as subsequent sponsorship. The average value of the multiplier over these years is 2.12 when accompanying family are included and 1.59 when they are excluded. One feature of the results is that the value of the (total) multiplier increases over time, from 1.33 in 1972 to 2.58 in 1997 (Yu, 2008, p. 190). This would be consistent with shifts in the composition of immigrants towards source countries with higher than average sponsorship rates. Yu also calculated differences between source regions in the average value of the multiplier for 1972-97. The highest value is for immigrants from Asia (2.79) followed by Latin America (2.25), the Middle East (2.03), Europe (1.40), Oceania/other (1.25), North America (1.14), and Africa (1.06) (Yu, 2008, p 192). Other evidence also suggests that multipliers differ across different origin groups. Borjas and Bronars (1991) examined arrival cohorts of immigrants residing in the same household in 1980. Less than ten percent of European Immigrants arriving in 1970-4 had a subsequent arrival living with them while the rate for those born in the Korea, Mexico or the Philippines was more than 20 percent.

\section{Model and data}

There is a large literature on the effects of networks in international migration which paints a picture of cumulative causation through a variety of different mechanisms (Massey et al., 1993; Carrington et al., 1996). A number of econometric studies also lend support to socalled friends and relatives effect on the flow international migration (Yang, 1995, Ch. 5; Clark et al., 2007; Pedersen et al., 2008; Hatton and Williamson, 2011; Beine et al., 2011a,b). These studies estimate the effects of the migrant stock in the presence of other variables but they do not focus on specific entry channels. Here I explore the relationship between the stock of immigrants and the subsequent flow over the period that the Hart-Celler Act was in force. I investigate two questions. First, how does the effect of the migrant stock 
depend on source country conditions, specifically the level of income per capita? And second, how does the strength of this effect vary across different classes of admission?

The model to be estimated is as follows:

$\frac{M_{i, t+1}}{P_{i, t}}=\alpha_{1}+\alpha_{2} \frac{S_{i, t}}{P_{i, t}}+\alpha_{3} X_{i, t}+\alpha_{4} \frac{S_{i, t}}{P_{i, t}} * X_{i, t}+Z_{i, t}+u_{i}+d_{t}+e_{i, t}$

Where, $M_{i, t+1}$ is the flow of immigrants from country $i$ between time $t$ and $t+1, s_{i, t}$ is the stock of foreign-born from country $i$ at the beginning of the period and $P_{i, t}$ is the source country population. $X_{i, t}$ is per capita income in the source country and this also appears as an interaction with the migrant stock. If the migrant stock effect is stronger for poor source countries then $\alpha_{4}$ will be negative. That would also imply that the effect of source country income is more negative the larger is the migrant stock. This is consistent with the idea that the larger is the existing network, the less income constrained are potential immigrants from poor countries. $Z_{i, t}$ is a vector of other source country variables that influence the decision to migrate and $u_{i}$ is a country fixed effect, which absorbs all time invariant effects, such as distance, language and culture. Finally, conditions in the United States are absorbed by the period fixed effects, $d_{t}$.

The data for immigration by country of birth come from the data files of the Immigration and Naturalization Service. They are for those gaining permanent residency and they exclude temporary admissions and legalisations. These data are available from fiscal year 1972, and to match with other variables in the dataset they are aggregated into five year totals for each of 102 countries. The immigrant stock comes from birthplaces as recorded in the US census and is interpolated between censuses using the immigrant flow. The timing is such that, for example, the total immigrant inflow for fiscal years 1972-6 is related to the stock in 1970, and the flow for 1977-81 is related to the stock in 1975. It is important to recognise that the sponsorship lag could be quite long. The waiting time between permanent residency and citizenship (required for sponsorship under preferences 1, 4 and 5) was five years. And while the evidence suggests that sponsorship typically took place within a few years of gaining citizenship, there could be a further wait because of backlogs in the preference system. ${ }^{20}$ However, the total immigrant stock consists of those who had migrated at any time in the past and so alternative measures of the stock are constructed for those who arrived within the last ten years and those who arrived within the last 20 years. ${ }^{21}$ Details of the construction of immigrant stock and flow variables are discussed in the data appendix.

\footnotetext{
${ }^{20}$ During the1970s and 1980s the median length of residence before naturalization was around eight years, which includes the five year waiting period. For immigrant from Asia and Africa it was 6-7 years (Statistical Yearbook, 1987, p. xxxvii)

${ }^{21}$ Where the immigrant stock is defined over the previous ten years the average lag between the arrival of a member of the stock and the arrival of a member of the subsequent flow is about nine years. For example, the approximate average year of arrival for a member of the ten-year immigrant stock in 1970 would be 1965 and
} 
The other explanatory variables are country income, education and demography. GDP per capita is taken from the Penn World Tables version 6.3. The share of the source country population aged 20-34 with some tertiary education is taken from Barro and Lee (2012). This variable provides a test of the hypothesis that the growth in source country education levels helped to boost immigration. Also included is the total fertility rate a decade earlier, taken from the World Bank. This is an indirect measure of family size-a factor that might be expected to influence the potential number of family reunification migrants.

Table 5 provides regressions for five-year immigration inflows with fixed source country effects and period dummies. The first column uses the total immigrant stock and its interaction with GDP per capita. While the main effect of the immigrant stock is positive the interaction with GDP is strongly negative. Thus, as expected, the migrant stock effect is larger the poorer is the country. As GDP is measured in thousands of 2005 US dollars, the migrant stock effect for a country such as China, with a per capita income of $\$ 1000$, is that every 100 of the stock adds $(0.401-0.024(1)) * 100=37.7$ further immigrants in the subsequent five year period. On the other hand for a country like the UK or France with a per capita GDP of $\$ 16,000$, the migrant stock effect would be close to zero. Thus the effect of the existing migrant stock varies widely depending on source country income and living standards. Because of the interaction, the effect of source country GDP also varies. For a country with a (relatively small) migrant stock to source to population ratio of 2 per thousand the effect of income on immigration is positive $(0.101-0.024(2))=0.053$. Thus the migration rate is more constrained by low income where migrant networks are very sparse. According to this estimate, for countries with an existing migrant stock in the US of more than about four per thousand source country income has the conventional negative effect on immigration, and the larger the stock the more negative the income effect will be.

The second and third columns use different measures of the immigrant stock. In each case the main immigrant stock effect is positive and the interaction effect is negative. Not surprisingly, the coefficients become larger in magnitude as the definition of the migrant stock is narrowed. An increase of 100 in the ten year migrant stock leads to a flow over five years of 68 from a source country with income of $\$ 1000$ but only 7 from one with an income of $\$ 16,000$. By contrast with income and the migrant stock, the other variables in the table have insignificant coefficients. The effect of tertiary education in the source country is close to zero. This is consistent with an immigration policy which did not, in the event, select positively for education. This could also reflect the poverty constraint such that positive selection would be stronger at lower income levels. But when an interaction between the share tertiary educated and GDP added to column 1 is insignificant (' $t=0.45$ ). The lagged fertility rate, while always positive, is not significant suggesting that demographic effects are relatively weak. Finally the dummy for the Western Hemisphere in the earlier years is

the average year of arrival for the subsequent flow would be 1974 . While some members of the stock would be too recent to be US citizens they could still sponsor immediate relatives through the second preference, requiring only permanent resident status. 
positive. This suggests that Western Hemisphere immigrants were crowded out by Eastern Hemisphere immigrants in the competition for numerically limited visas after the hemispheric quotas were merged into the worldwide numerical limit in $1978 .{ }^{22}$

Before moving to a more disaggregated analysis it is worth considering possible bias in the coefficients. Given that the explanatory variables all occur in advance of the outcome reverse causality should not be a problem. And heterogeneity across countries is eliminated by the use of fixed country effects. Nevertheless, endogeneity between the migrant stock and the subsequent flow could arise as the result of measurement error (due to undocumented immigrants) or because of some persistence in unobserved source country shocks. In the instrumental variables regressions of Table 6 the migrant stock and its interaction with GDP per capita are both instrumented. The variables used as instruments are the migrant stocks in other rich country destinations from the same source country and for the same period. The destination countries are Australia, Canada, the UK, France, Germany and Sweden. The results in Table 6 are similar to those in Table 5 except that the coefficients on the instrumented variables are larger in absolute magnitude. Thus, the results from instrumental variables do not suggest that the coefficients in Table 4 are biased upwards due to endogeneity.

The total flow of immigration is the result of entry through different channels with different criteria for admission. We would therefore expect that to be reflected in differences in the coefficients across classes of admission. Accordingly, the five-year immigration rates have been disaggregated into four broad classes. The first is employment based immigrantsessentially those admitted under preferences 3 and 6 . The second is non-immediate family members admitted under preferences 1, 2 and 5. The third group is immediate relatives who were admitted outside of the overall quota. Finally the fourth category, all other immigrants, includes those admitted under preferences 7 and 8 and those admitted outside the numerical limit but excluding immediate family members. These are largely refugees and others who were given special dispensation.

The results are presented in Table 7, where the migrant stock variable used is for those who had been in the US for ten years or less. The first column shows that for the relatively small employment stream none of the explanatory variables have a significant effect. In particular there is no evidence of chain migration effects, which is a little surprising in the light of the literature on transnational employment networks. And it is notable that the coefficient on the share with tertiary education remains small and relatively insignificant. Thus, even through the employment stream, there is little evidence that immigration was driven by source country education. The second column, for the non-immediate relative preferences gives a large positive coefficient on the immigrant stock and a negative coefficient on the interaction with GDP which is only marginally significant. Nevertheless, the pattern of

\footnotetext{
${ }^{22}$ This effect seems to have dominated the increase in admission routes that became available when the preference system was applied to the Western Hemisphere in 1976.
} 
coefficients more strongly resembles that for total migration. Here also the Western Hemisphere dummy is large and positive, reflecting the fact that in the absence of preferences for the Western Hemisphere before 1978 all numerically limited immigrants are treated as family based.

Not surprisingly, the third regression, for immediate relatives, also resembles the results for total immigration, this time with strongly significant coefficients on the migrant stock and its interaction with GDP per capita. Finally the heterogeneous group in the last column produces the somewhat anomalous result of a negative coefficient on the interaction term, which may simply reflect the fact that these are mainly refugees. Overall the results are consistent with the idea that the relationship between the stock of immigrants and the subsequent flow does indeed work through the family reunification channels.

\section{Cumulative effects}

The results obtained here use a completely different method to the studies based on calculating sponsorship rates. However some comparison can be made by taking a one period increase in the immigrant stock and allowing its effects to cumulate across periods. The results for unweighted averages of countries using the regression coefficients in the third column of Table 5 are presented in the upper panel of Table 8. On average the number of additional immigrants from an initial shock of 100 immigrants is 32.5 after ten years and 34.7 after twenty years. These immigration multipliers are more modest than those estimated from sponsorship rates, partly because of the different method but also because the base for the initial immigration shock is all immigrants and not just principals. ${ }^{23}$ More important, although the average multiplier effects are far from explosive, they vary widely between source regions with different average income levels. For Europe only 15 additional immigrants are generated over 20 years while for Asia, the Americas and Africa/Oceania the comparable figures are 65.4, 75.8 and 89.6.

While the upper panel of Table 8 shows the effect of a rise in the migrant stock by 100 for one period only, the lower panel shows the effect of a sustained shock to the immigrant stock. In this case each 5-year period's immigration adds to the 10-year immigration stock for two periods, which in turn creates further immigration. This is intended to capture the effect of an underlying shift in the immigration rate, independent of the friends and relatives effect. On average this leads to a doubling of the inflow after 20 years. For Europe the increase is modest, just an increase to 143 from a base of 100. But for immigration from Asia the figure is 269 and for the Americas it is 293. Thus although the immigration multiplier as conventionally defined is relatively modest, if the immigration shock is persistent, then once an immigration flow becomes established the numbers cumulate quite rapidly.

\footnotetext{
${ }^{23} \mathrm{Yu}$ (2008. p. 190) estimated that principal immigrants were accompanied by an average of 0.15 spouses and 0.38 children. These principals would then bring a further 1.59 immigrants. But if the accompanying family members are included in the base then the multiplier falls to $1.59 /(1+0.15+0.38)=1.03$.
} 


\section{Conclusion}

The 1965 Amendments to the Immigration Act are often seen as a watershed in immigration policy, which transformed the face of US immigration in the decades that followed. While contemporary legislators anticipated some of these effects, the changes in the scale and structure of immigration, and the speed with which they took place, were not foreseen. Against the background of the national origins system that had been in place for more than a generation, past experience offered little basis upon which to predict. Looking back, historians have largely concurred with the view that the consequences were largely unintended. This paper sheds further light on exactly what caused such a dramatic increase in immigration and such a radical shift in immigrant origins during the two decades that the Hart-Celler Act was in force. In fact several different components contributed and they interacted to produce unexpected results.

Some of the ingredients are obvious, others less so. The most obvious is the key provision of the Hart-Celler Act, the abolition of the national origins system. The full utilisation of the numerical quota and the associated increases in immediate relatives were direct and deliberate results of the reform. Yet even before this, the volume of immigration had been steadily increasing, partly due to the modest liberalisation of the McCarran Walter Act, but mainly because of the continuing admission of refugees outside the mainstream immigration system. Although the Hart-Celler Act attempted to cap refugee numbers, the continued use of parole authority and the shift in refugee origins provided a foundation for further inflows from countries and regions with little previous immigration history. And while the 1965 Act placed a ceiling on Western Hemisphere immigration, the abolition of the Bracero Program and the shift from restrictive informal procedures to more formal processes of labor certification expanded the scope for permanent immigration from Latin America.

Those who framed the legislation of 1965 stressed two important features, neither of which operated in the way that was anticipated, and these are reflected in the empirical results presented above. The first was the shift in the burden of responsibility for labor certification, which it was thought, would restrict access through the employment preferences for potential immigrants from developing countries. Growing education could have helped, but source country education seems to have had little effect on access via employment. The second was the weight given to family preferences, which it was thought would largely preserve the pre-existing source country mix. The clear evidence is that the immigration multiplier, operating through the family preferences and through uncapped immediate relatives, was much larger for poorer source countries. As a result, the preceding experience with European immigration would have been a poor predictor of what was to follow. 


\section{References}

Alba, R. and Nee, V. (2003), Remaking the American Mainstream: Assimilation and Contemporary Immigration, Cambridge MA: Harvard University Press.

Anker, D. E. and Posner, M. H. (1981-2), "The Forty Year Crisis: A Legislative History of the Refugee Act of 1980," San Diego Law Review, 19, pp. 9-89.

Borjas, G. J. (1999), Heaven's Door: Immigration Policy and the American Economy, Princeton NJ: Princeton University Press.

Bean, F. D. and Stevens, G. (2003), America's Newcomers and the Dynamics of Diversity, New York: Russell Sage Foundation.

Beine, M., Docquier, F, and Özden, C. (2011a), "Diasporas," Journal of Development Economics, 95, pp. 30-41.

Beine, M., Docquier, F, and Özden, C. (2011b), "Dissecting Network Externalities in International Migration," Louvain: INRES Discussion Paper 2011-22.

Briggs, V. M. (1984), Immigration Policy and the American Labor Force, Baltimore: Johns Hopkins University Press.

Briggs, V. M. (2003), Mass Immigration and the National Interest: Policy Directions for the New Century ( ${ }^{\text {rd }}$ Edn.), New York: M. E. Sharpe Inc.

Borjas, G. J. and Bronars, S. G. (1991), "Immigration and the Family," Journal of Labor Economics, 9, pp. 123-148.

Carrington, W. J., Detragiache, E. and Vishwanath, T. (1996), "Migration with Endogenous Moving Costs," American Economic Review, 86, pp. 909-30.

Center for Immigration Studies, (1995) "Three Decades of Mass Immigration: the Legacy of the 1965 Immigration Act" http://www.cis.org/node/145.

Chin, G. J. (1996) "The Civil Rights Revolution comes to Immigration Law: A New Look at the Immigration and Nationality Act of 1965," North Carolina Law Review, 75, pp. 273-345.

Clark, X., Hatton, T. J. and Williamson, J. G. (2007), “Explaining U.S. Immigration, 19711998," Review of Economics and Statistics, 89, pp. 359-373.

Daniels, R. (2004), Guarding the Golden Door, American Immigration Policy and Immigrants since 1882, New York: Hill and Wang.

Greenwood, M. J. and McDowell, J. M. (1999), Legal U.S. Immigration: Influences on Gender, Age, and Skill Composition, Kalamazoo: W.E. Upjohn Institute Press.

Hanson, G. H. (2005) Why Does Immigration Divide America? Public Finance and Political Opposition to Open Borders, Washington, DC: Institute for International Economics.

Hatton, T. J. and Williamson, J. G. (2011) "Are Third World Emigration Forces Abating?" World Development, 39, pp. 20-32. 
Huntington, S. P. (2004), Who Are We: The Challenges to America's National Identity, New York: Simon and Schuster.

Jasso, G. and Rosenzweig, M. R. (1986), "Family Reunification and the Immigration Multiplier: U.S. Immigration Law, Origin-Country Conditions, and the Reproduction of Immigrants," Demography, 23, pp. 291-311.

Jasso, G. and Rosenzweig, M. R. (1989), "Sponsors, Sponsorship Rates and the Immigration Multiplier," International Migration Review, 23, pp. 856-888.

Jasso, G. and Rosenzweig, M. R. (1990), The New Chosen People: Immigrants to the United States, New York: Russel Sage Foundation.

Keely, C. B. (1971), "Effects of the Immigration Act of 1965 on Selected Population Characteristics of Immigrants to the United States," Demography, 8, pp. 157-169.

Keely, C. B. (1975), "Effects of U. S. Immigration Law on Manpower Characteristics of Immigrants," Demography, 12, pp. 179-191.

Kennedy, E. M. (1981), "Refugee Act of 1980," International Migration Review, 15, pp. 141156.

Kennedy, J. F. (1964), A Nation of Immigrants ( $2^{\text {nd }}$ Edn.), New York: Harper and Row.

Lee, K. K. (1998), Huddled Masses, Muddled Laws: Why Contemporary Immigration Policy Fails to Reflect Public Opinion, Westport CT: Praeger.

Kraly, E. P. (1990), "U.S. refugee Policies and Refugee Migration," in R. W. Tucker, C. B. Keely and L. Wrigley, Immigration and U.S. Foreign Policy, Boulder CO: Westview Press.

Massey, D. S., Arango, J., Hugo, G., Kouaouci, A. Pellegrino, A. and Taylor, J. E. (1993), "Theories of International Migration: A Review and Appraisal," Population and Development Review, 19, pp. 431-466.

Mott, F. L. (1966), "The Immigrant Worker," Annals of the American Academy of Political and Social Science, 367, pp. 23-32.

North, D. S. (1971), Alien Workers: A Study of the Labor Certification Program, Washington DC: TransCentury Corp.

North, D. S. and Houstoun, M. F. (1979), Illegal Aliens: Their Characteristics and Role in the U.S. Labor Market: An Exploratory Study, Industrial Relations University of California: Institute of Urban and Regional Development.

Passel, J. S. (2007), "Unauthorized Migrants in the United States: Estimates, Methods, and Characteristics," Paris: OECD Social, Employment and Migration Working Paper No. 57.

Pedersen, P. J., Pytlikova, M. and Smith, N. (2008), "Selection and Network EffectsMigration Flows into OECD Countries 1990-2000," European Economic Review, 52, pp. 1160-1186. 
Portes, A. and Rumbaut, R. G. (2006), Immigrant America: A Portrait (3rd Edn.), Berkeley CA: University of California Press.

Reimers, D. M. (1983), “An Unintended Reform: The 1965 Immigration Act and Third World Immigration to the United States," Journal of American Ethnic History, 3, pp. 9-28.

Reimers, D. M. (1992), Still the Golden Door: The Third World Comes to America, New York: Columbia University Press.

Rubin, E. J. R. and Mancini, M. A. (1976-7), "Overview of the Labor Certification Requirement for Intending Immigrants," San Diego Law Review, 14, pp. 76-110.

Smith, J. P. and Edmonston, B. (1997), The New Americans: Economic Demographic, and Fiscal Effects of Immigration, Washington DC: National Academy Press.

Schwartz, A. P. (1966), "The Role of the State Department in the Administration and Enforcement of the New Immigration Law," Annals of the American Academy of Political and Social Science, 367, pp. 93-104.

Steele, R. D. (1981), "In Defense of the Permanent Resident: Alleged Defects Relating to Alien Labor Certifications," San Diego Law Review, 19, pp. 119-148.

Stern, W. S. (1975), "HR 2580: The Immigration and Nationality Amendments of 1965: A Case Study," unpublished dissertation, New York University.

U.S. General Accounting Office (1988), Immigration: The Future Flow of Legal Immigration to the United States, Washington DC: U.S. Government Printing Office.

Warren, R. E. and Passel, J. S (1987), "A Count of the Uncountable: Estimates of Undocumented Aliens Counted in the 1980 United States Census." Demography, 24, pp. 375-393.

Woodrow-Lafield, K. A. (1994), "Potential Sponsorship by IRCA-Legalized Immigrants," Albany, NY: U.S. Commission on Immigration Reform Research Paper.

Yang, P. Q. (1995), Post-1965 Immigration to the United States: Structural Determinants, Westport CT: Praeger.

Yu, B. (2008), Chain Migration Explained: The Power of the Immigration Multiplier, New York: LFB Scholarly Publishing.

Zolberg, A. (2006), A Nation by Design: Immigration Policy in the Fashioning of America, Cambridge MA: Harvard University Press. 


\section{Data Appendix}

Immigration to the United States: The US Department of Justice, Immigration and Naturalization Service publishes various tabulations of immigrants in its Statistical Yearbooks, and before 1978, in its Annual Report. The microdata underlying these reports, is available as a series of files (one for each year) under the title "Immigrants Admitted to the United States", which together with the codebooks, was supplied by the Inter-University Consortium for Political and Social Research. These data were used to construct the number of immigrants by country of birth and by different routes of entry for each of the fiscal years from 1972 to 1991 . Fiscal year 1972 is $1^{\text {st }}$ July 1971 to $30^{\text {th }}$ June 1972 , but from 1977 the fiscal year changed from $1^{\text {st }}$ October to $30^{\text {th }}$ September. The third quarter of 1976 (for which there is a separate file) has been omitted from the calculations. These data record all admissions to permanent residency, including both new arrivals and adjustments of status, but excluding visitors and temporary migrants.

US Immigrant Stock: Stock by country of birth for each census year is taken from: Gibson, C. and Jung, K. (2006), "Historical Census Statistics on the Foreign-born Population of the United States: 1850-2000," Census Bureau, Population Division, Working Paper No. 81 . The years ending in ' 5 ' are interpolated between the census benchmarks using the relationship: $S_{i, t+1}=M_{i, t+1}+d S_{i, t}$ where $S_{i, t}$ is the immigrant stock, born in country $i$ observed in year $t, M_{t}$ is the flow during the subsequent year, and $d$ is a 'depreciation rate', which reflects deaths and return migration. This depreciation rate is calculated for each country/decade using an iterative procedure beginning with $S_{i, t}$, such that the value of $S_{i, t+10}$ obtained by cumulating forward is reconciled with that of the next census benchmark. The immigrant stock present for 10 and 20 years are obtained by applying the shares of those present for different durations to the total stock. The ratios are calculated for each country/census year using the IPUMS census samples from: http://usa.ipums.org/usa/.

GDP per capita and Population: Constant price (\$US, 2005) GDP per capita and Population from Alan Heston, A., Summers, R. and Aten, B. (2009), “Penn World Table Version 6.3," Center for International Comparisons of Production, Income and Prices at the University of Pennsylvania, at http://pwt.econ.upenn.edu/php site/pwt63/pwt63 form.php.

Educational attainment: For those aged 20-35 at five year intervals taken from Barro and Lee at: http://www.barrolee.com/data/dataexp.htm, See Barro ,R. and Lee, J. W. (2010), "A New Data Set of Educational Attainment in the World, 1950-2010" NBER Working Paper No. 15902. Missing countries are represented by the average for countries in the same region.

Total Fertility Rate: From the World Bank Databank at: http://databank.worldbank.org/ddp/home.do?Step=2\&id=4\&hActiveDimensionld=WDI Series.

Other migrant stock: Migrant stock in Australia, Canada, UK France, Germany and Sweden by source country from World Bank Global Bilateral Database at: http://data.worldbank.org/datacatalog/global-bilateral-migration-database. The years ending in ' 5 ' are linearly interpolated between the ten-year benchmarks. Refugee stock by country of origin is from United Nations High Commissioner for Refugees at: http://www.unhcr.org/pages/4a0174156.html. 
The countries that are used in the empirical work are all those for which the explanatory variables could be found or constructed. They are as follows:

\begin{tabular}{|l|l|l|l|}
\hline Europe & Asia & Africa & North America \\
\hline Albania & Afghanistan & Algeria & Canada \\
\hline Austria & Bangladesh & Cameroon & Mexico \\
\hline Belgium & Cambodia & Congo, D. R. (Zaire) & Barbados \\
\hline Bulgaria & China & Egypt & Cuba \\
\hline Czechoslovakia & Cyprus & Ghana & Dominican Republic \\
\hline Denmark & Hong Kong & Kenya & Haiti \\
\hline Finland & India & Liberia & Jamaica \\
\hline France & Indonesia & Libya & Trinidad \& Tobago \\
\hline Germany & Iran & Morocco & Belize \\
\hline Greece & Iraq & Senegal & Costa Rica \\
\hline Hungary & Israel & Sierra Leone & El Salvador \\
\hline Iceland & Japan & South Africa & Guatemala \\
\hline Ireland & Jordan & Sudan & Honduras \\
\hline Italy & Korea & Tanzania & Nicaragua \\
\hline Luxembourg & Kuwait & Tunisia & Panama \\
\hline Malta & Laos & Uganda & South America \\
\hline Netherlands & Malaysia & Zambia & Argentina \\
\hline Norway & Nepal & Zimbabwe & Bolivia \\
\hline Poland & Pakistan & Oceania & Brazil \\
\hline Portugal & Philippines & Australia & Chile \\
\hline Romania & Saudi Arabia & Fiji & Colombia \\
\hline Soviet Union & Singapore & New Zealand & Ecuador \\
\hline Spain & Sri Lanka & Tonga & Guyana \\
\hline Sweden & Syria & & Paraguay \\
\hline Switzerland & Thailand & Purkey & Uruguay \\
\hline United Kingdom & Vietnam & Venezuela \\
\hline Yugoslavia & & & \\
\hline
\end{tabular}


Table 1: Source Region Composition of US immigration 1920-2009

\begin{tabular}{|c|c|c|c|c|c|c|c|c|c|}
\hline & $\begin{array}{r}1920 \text { to } \\
1929\end{array}$ & $\begin{array}{r}1930 \text { to } \\
1939\end{array}$ & $\begin{array}{r}1940 \text { to } \\
1949\end{array}$ & $\begin{array}{r}1950 \text { to } \\
1959\end{array}$ & $\begin{array}{r}1960 \text { to } \\
1969\end{array}$ & $\begin{array}{r}1970 \text { to } \\
1979\end{array}$ & $\begin{array}{r}1980 \text { to } \\
1989\end{array}$ & $\begin{array}{r}1990 \text { to } \\
1999\end{array}$ & $\begin{array}{r}2000 \text { to } \\
2009\end{array}$ \\
\hline Europe & 59.6 & 63.5 & 55.2 & 56.2 & 35.3 & 19.4 & 10.7 & 13.8 & 13.1 \\
\hline Ireland, Germany, UK & 21.7 & 29.9 & 31.2 & 32.8 & 14.6 & 5.2 & 4.2 & 3.2 & 3.0 \\
\hline Other NW Europe & 10.2 & 9.2 & 10.9 & 7.0 & 4.9 & 1.6 & 1.3 & 1.0 & 1.2 \\
\hline South Europe & 15.9 & 14.7 & 8.0 & 10.0 & 12.0 & 9.4 & 2.5 & 1.5 & 0.7 \\
\hline East Europe & 11.9 & 9.7 & 5.1 & 6.3 & 3.8 & 3.2 & 2.7 & 8.1 & 8.2 \\
\hline Asia & 3.0 & 2.7 & 4.0 & 5.4 & 11.2 & 33.1 & 38.3 & 29.3 & 33.7 \\
\hline East Asia & & & & 2.8 & 5.1 & 12.0 & 12.3 & 8.6 & 10.1 \\
\hline Other Asia & & & & 2.7 & 6.0 & 21.1 & 26.0 & 20.7 & 23.6 \\
\hline America & 37.0 & 32.9 & 38.3 & 36.9 & 52.1 & 44.8 & 43.2 & 52.6 & 43.1 \\
\hline Canada & 22.1 & 23.3 & 18.8 & 14.1 & 13.5 & 4.2 & 2.5 & 2.0 & 2.3 \\
\hline Mexico & 11.6 & 4.7 & 6.6 & 11.0 & 13.7 & 14.6 & 16.2 & 28.2 & 16.5 \\
\hline Caribbean & 1.9 & 2.6 & 5.4 & 4.6 & 13.3 & 16.7 & 12.7 & 10.3 & 10.2 \\
\hline Central America & 0.4 & 1.0 & 2.4 & 1.6 & 3.1 & 2.8 & 5.4 & 6.2 & 5.7 \\
\hline South America & 1.0 & 1.4 & 2.3 & 3.1 & 7.8 & 6.4 & 6.4 & 5.8 & 8.3 \\
\hline Africa & 0.1 & 0.3 & 0.8 & 0.5 & 0.7 & 1.7 & 2.3 & 3.5 & 7.4 \\
\hline Oceania & 0.2 & 0.5 & 1.7 & 0.5 & 0.7 & 0.9 & 0.7 & 0.6 & 0.6 \\
\hline Not Specified & 0.0 & - & 0.0 & 0.5 & 0.0 & 0.0 & 4.9 & 0.3 & 2.1 \\
\hline Total & 100.0 & 100.0 & 100.0 & 100.0 & 100.0 & 100.0 & 100.0 & 100.0 & 100.0 \\
\hline Number (000s) & 4,296 & 699 & 857 & 2,499 & 3,214 & 4,248 & 6,244 & 9,775 & 10,299 \\
\hline
\end{tabular}

Source: Statistical Yearbook 2010 Table 2. Note: based on country of last residence; East Asia does not include Vietnam. 


\section{Table 2: Schedule of Eastern Hemisphere Preferences in 1952 and 1965 Immigration Acts}

\begin{tabular}{|c|c|}
\hline Immigration and Nationality Act, 1952 & Amendments to the Immigration Act, 1965 \\
\hline $\begin{array}{l}\text { (1) First preference: Highly skilled immigrants whose } \\
\text { services are urgently needed in the U. S. and the spouse } \\
\text { and children of such immigrants. } 50 \% \text { plus any not required } \\
\text { for } 2 \text { nd and 3rd preference. }\end{array}$ & $\begin{array}{l}\text { (1) First preference: Unmarried sons and daughters of U. S. } \\
\text { citizens. Not more than } 20 \% \text {. }\end{array}$ \\
\hline $\begin{array}{l}\text { (2) Second preference: Parents of U. S. citizens over the age } \\
\text { of } 21 \text { and unmarried sons and daughters of U. S. citizens. } \\
30 \% \text { plus any not required for 1st and 3rd preference. }\end{array}$ & $\begin{array}{l}\text { (2) Second preference: Spouse and unmarried sons and } \\
\text { daughters of an alien lawfully admitted for permanent } \\
\text { residence. } 20 \% \text { plus any not required for first preference. }\end{array}$ \\
\hline $\begin{array}{l}\text { (3) Third preference: Spouse and unmarried sons and } \\
\text { daughters of an alien lawfully admitted for permanent } \\
\text { residence. } 20 \% \text { plus any not required for first or second } \\
\text { preference. }\end{array}$ & $\begin{array}{l}\text { (3) Third preference: Members of the professions and } \\
\text { scientists and artists of exceptional ability. Not more than } \\
10 \% \text {. }\end{array}$ \\
\hline $\begin{array}{l}\text { (4) Fourth preference: Brothers, sisters, married sons and } \\
\text { daughters of U. S. citizens and an accompanying spouse and } \\
\text { children. } 50 \% \text { of numbers not required for first three } \\
\text { preferences. }\end{array}$ & $\begin{array}{l}\text { (4) Fourth preference: Married sons and daughters of U. S. } \\
\text { citizens. } 10 \% \text { plus any not required for first three } \\
\text { preferences. }\end{array}$ \\
\hline \multirow{4}{*}{$\begin{array}{l}\text { 5) Nonpreference: Applicants not entitled to one of the } \\
\text { above preferences. } 50 \% \text { of numbers not required for first } \\
\text { three preferences, plus any not required for fourth } \\
\text { preference. }\end{array}$} & $\begin{array}{l}\text { (5) Fifth preference: Brothers and sisters of U. S. citizens. } \\
24 \% \text { plus any not required for first four preferences. }\end{array}$ \\
\hline & $\begin{array}{l}\text { (6) Sixth preference: Skilled and unskilled workers in } \\
\text { occupations for which labor is in short supply in U. S. Not } \\
\text { more than } 10 \% \text {. }\end{array}$ \\
\hline & $\begin{array}{l}\text { (7) Seventh preference: Refugees to whom conditional } \\
\text { entry or adjustment of status may be granted. Not more } \\
\text { than } 6 \% \text {. }\end{array}$ \\
\hline & $\begin{array}{l}\text { 8) Nonpreference: Any applicant not entitled to one of the } \\
\text { above preferences. Any numbers not required for } \\
\text { preference applicants }\end{array}$ \\
\hline
\end{tabular}

Source: Keely, 1971, p. 160. 
Table 3: Refugees Granted Permanent Residence Status, 1946-2000

\begin{tabular}{|c|r|r|r|r|r|r|}
\hline & $1946-50$ & $1951-60$ & $1961-70$ & $1971-80$ & $1981-90$ & \multicolumn{1}{l|}{$\begin{array}{l}1991- \\
2000\end{array}$} \\
\hline Europe & 211,983 & 456,146 & 55,235 & 71,858 & 155,512 & 426,565 \\
\hline W Europe & 41,563 & 88,683 & 4,032 & 587 & 1,809 & 2,128 \\
\hline S Europe & 779 & 93,121 & 7,259 & 6,170 & 2,564 & 1,242 \\
\hline E Europe & 108,310 & 214,828 & 42,936 & 33,751 & 78,723 & 88,339 \\
\hline USSR & 61,331 & 59,514 & 1,008 & 31,350 & 72,416 & 334,856 \\
\hline Asia & 1,106 & 33,422 & 19,895 & 210,683 & 712,092 & 351,347 \\
\hline Africa & 20 & 1,768 & 5,486 & 2,991 & 22,149 & 51,649 \\
\hline Oceania & 7 & 75 & 21 & 37 & 22 & 291 \\
\hline Americas & 195 & 905 & 132,191 & 253,877 & 123,826 & 191,190 \\
\hline N America & 3 & 6 & 131,557 & 252,130 & 114,214 & 154,751 \\
and Carib & 160 & 825 & 511 & 503 & 7,626 & 30,582 \\
\hline C America & 32 & 74 & 123 & 1,244 & 1,986 & 5,857 \\
\hline S America & 36 & 55 & 15 & 1 & 19 & 224 \\
\hline Unknown & 213,347 & 492,371 & 212,843 & 539,447 & $1,013,620$ & $1,021,266$ \\
\hline Total & & & & & &
\end{tabular}

Source: INS Statistical Yearbook 2000, Table 30. Notes: These refugees were admitted under the following programmes (total number in parentheses): Presidential Directive of 12/22/45 (40,324); Displaced Persons Act of 6/25/48 (409,696); Orphan Act of 7/29/53 (466); Refugee Relief Act of 8/7/53 (189,025); Refugee-Escapee Act of 9/11/57 (29,462); Hungarian Refugee Act of 7/25/58 (30,752); Azores \& Netherlands Refugee Act of 9/2/58 (22,213); Refugee Relatives Act of 9/22/59 (1,820); Fair Share Refugee Act of 7/14/60 (19,800); Refugee Conditional Entrants Act of 10/3/65 (142,103); Cuban Refugee Act of 11/2/66 (610,568); Indochinese Refugee Act of 10/28/77 (175,168); Refugee Parolee Act of 10/5/78 $(139,294)$; Refugee Act of 1980, 3/17/80 $(1,682,203)$. See INS Statistical Yearbook 2000, Table 29. 
Table 4: Admission Categories and Occupations in 1982 (percent)

\begin{tabular}{|c|c|c|c|c|c|c|}
\hline & All & Europe & Asia & $\begin{array}{l}\text { Africa \& } \\
\text { Oceania }\end{array}$ & $\begin{array}{l}\text { North } \\
\text { America }\end{array}$ & $\begin{array}{l}\text { South } \\
\text { America }\end{array}$ \\
\hline \multicolumn{7}{|c|}{ Class of admission (all immigrants) } \\
\hline Employment preferences \% & 4.4 & 8.8 & 4.5 & 10.0 & 2.1 & 2.1 \\
\hline Family preferences $\%$ & 38.9 & 26.1 & 31.1 & 35.3 & 54.7 & 64.1 \\
\hline Immediate relatives $\%$ & 28.3 & 35.8 & 21.2 & 44.0 & 36.9 & 30.9 \\
\hline Other admissions \% & 28.4 & 29.2 & 43.3 & 10.7 & 6.2 & 2.9 \\
\hline \multicolumn{7}{|l|}{ Adult immigrants aged $16+$} \\
\hline With labor certificate $\%$ & 5.4 & 8.0 & 4.8 & 8.2 & 4.7 & 5.9 \\
\hline With an occupation \% & 43.4 & 48.0 & 36.6 & 49.1 & 52.8 & 43.8 \\
\hline Skilled \% (labor certificate) & 86.3 & 91.1 & 90.0 & 93.4 & 70.1 & 74.9 \\
\hline $\begin{array}{l}\text { Skilled \% (occupation but } \\
\text { no labor certificate) }\end{array}$ & 54.4 & 68.2 & 57.0 & 68.9 & 42.9 & 59.9 \\
\hline
\end{tabular}

Source: INS database for fiscal year 1982.

Table 5: Fixed Effects Regressions for Immigration by Source Country 1972-1991

\begin{tabular}{|l|c|c|c|}
\hline & Total Stock & 20 Year Stock & 10 Year Stock \\
\hline Immigrant stock/source & 0.401 & 0.492 & 0.722 \\
country population & $(6.09)$ & $(6.10)$ & $(5.68)$ \\
\hline (Immigrant stock/pop)*GDP & -0.024 & -0.028 & -0.041 \\
per capita in source country & $(6.69)$ & $(6.61)$ & $(6.36)$ \\
\hline GDP per capita in source & 0.101 & 0.099 & 0.137 \\
country & $(4.45)$ & $(4.39)$ & $(4.28)$ \\
\hline Share aged 20-34 tertiary & 0.003 & -0.012 & -0.041 \\
educated in source country & $(0.04)$ & $(0.16)$ & $(0.53)$ \\
\hline Total fertility rate (lagged) in & 0.623 & 0.601 & 0.680 \\
source country & $(1.46)$ & $(1.44)$ & $(1.63)$ \\
\hline Western hemisphere dummy & 1.605 & 1.634 & 2.633 \\
for 1972-8 & $(1.38)$ & $(1.47)$ & $(2.04)$ \\
\hline$R^{2}$ (within) & 0.468 & 0.679 & 0.694 \\
\hline Countries & 102 & 102 & 102 \\
\hline Observations & 408 & 408 & 408 \\
\hline
\end{tabular}

Note: ' $z$ ' statistics in parentheses are based on standard errors clustered by source country. 
Table 6: Instrumental Variables Regressions for Total Immigration

\begin{tabular}{|l|c|c|c|}
\hline & Total Stock & 20 Year Stock & 10 Year Stock \\
\hline Immigrant stock/source & 0.602 & 0.789 & 1.268 \\
country population & $(4.81)$ & $(5.01)$ & $(4.96)$ \\
\hline (Immigrant stock /pop)*GDP & -0.058 & -0.075 & -0.122 \\
per capita in source country & $(4.18)$ & $(4.29)$ & $(4.10)$ \\
\hline GDP per capita in source & 0.310 & 0.351 & 0.519 \\
country & $(2.88)$ & $(3.00)$ & $(3.31)$ \\
\hline Share aged 20-34 tertiary & 0.007 & -0.012 & -0.050 \\
educated in source country & $(0.04)$ & $(0.06)$ & $(0.25)$ \\
\hline Total fertility rate (lagged) in & -0.158 & -0.173 & -0.071 \\
source country & $(0.25)$ & $(0.26)$ & $(0.10)$ \\
\hline Western hemisphere dummy & 3.421 & 3.765 & 4.716 \\
for 1972-8 & $(2.46)$ & $(2.47)$ & $(3.05)$ \\
\hline R ${ }^{2}$ (within) & 0.198 & 0.200 & 0.216 \\
\hline Countries & 102 & 102 & 102 \\
\hline Observations & 408 & 408 & 408 \\
\hline
\end{tabular}

Table 7: Regressions for Immigration by Class of Admission

\begin{tabular}{|l|c|c|c|c|}
\hline & $\begin{array}{c}\text { Employment } \\
\text { preferences }\end{array}$ & $\begin{array}{c}\text { Family } \\
\text { preferences }\end{array}$ & $\begin{array}{c}\text { Immediate } \\
\text { family }\end{array}$ & $\begin{array}{c}\text { Other } \\
\text { immigrants }\end{array}$ \\
\hline Immigrant stock/source & 0.007 & 0.560 & 0.212 & -0.057 \\
country population & $(1.28)$ & $(3.11)$ & $(6.86)$ & $(0.48)$ \\
\hline (Immigrant stock /pop)*GDP & 0.000 & -0.015 & -0.008 & -0.018 \\
per capita in source country & $(0.06)$ & $(1.74)$ & $(6.70)$ & $(3.24)$ \\
\hline GDP per capita in source & 0.000 & 0.041 & 0.023 & 0.072 \\
country & $(0.09)$ & $(1.23)$ & $(4.20)$ & $(2.80)$ \\
\hline Share aged 20-34 tertiary & 0.006 & -0.113 & 0.14 & 0.052 \\
educated in source country & $(1.60)$ & $(1.57)$ & $(0.70)$ & $(0.88)$ \\
\hline Total fertility rate (lagged) in & -0.008 & 0.448 & 0.003 & 0.237 \\
source country & $(0.48)$ & $(1.10)$ & $(0.03)$ & $(0.60)$ \\
\hline Western Hemisphere & 0.034 & 5.18 & 0.609 & -3.192 \\
dummy for 1972-8 & $(0.91)$ & $(3.24)$ & $(1.91)$ & $(2.91)$ \\
\hline $\mathrm{R}^{2}$ (within) & 0.293 & 0.546 & 0.680 & 0.374 \\
\hline Countries & 102 & 102 & 102 & 102 \\
\hline Observations & 408 & 408 & 408 & 408 \\
\hline
\end{tabular}

Note: ' $z$ ' statistics in parentheses are based on standard errors clustered by source country. 
Table 8: Immigration Multipliers

\begin{tabular}{|l|r|r|r|r|r|}
\hline & All regions & Europe & \multicolumn{1}{l|}{ Asia } & Americas & \multicolumn{1}{l|}{$\begin{array}{l}\text { Africa/ } \\
\text { Oceania }\end{array}$} \\
\hline Original immigration & 100 & 100 & 100 & 100 & 100 \\
\hline Additional immigrants resulting from a temporary increase immigration \\
\hline After five years & 25.8 & 13.1 & 40.2 & 44.1 & 48.7 \\
\hline After ten years & 32.5 & 14.8 & 56.3 & 63.5 & 72.4 \\
\hline After twenty years & 34.7 & 15.1 & 65.4 & 75.8 & 89.6 \\
\hline Additional immigrants resulting from a sustained increase in immigration \\
\hline After five years & 125.8 & 113.1 & 140.2 & 158.5 & 148.1 \\
\hline After ten years & 142.1 & 120.5 & 168.3 & 204.8 & 183.7 \\
\hline After twenty years & 195.5 & 142.9 & 269.6 & 292.7 & 317.8 \\
\hline
\end{tabular}

Note: The figures in the upper panel are obtained by summing over time applying iteratively the relationship from the third column of Table 5 above: $\Delta M_{t+1}=(0.722-0.0041 \times G D P) \Delta M_{t}$ where $M$ is migration over a five year period and GDP is average GDP per capita between 1970 and 1985. These are unweighted averages for the countries in the dataset. Those in the lower panel cumulate the immigration flow starting with two periods with immigration raised by 100 , to reflect the 10 -year stock. Here the equation is: $M_{t+1}=(0.722-$ $0.0041 \times G D P) * 0.5\left(M_{t}+M_{t-1}\right)$.

Figure 1: Immigrants Admitted Within and Outside the Numerical Limit 1953 to 1991.

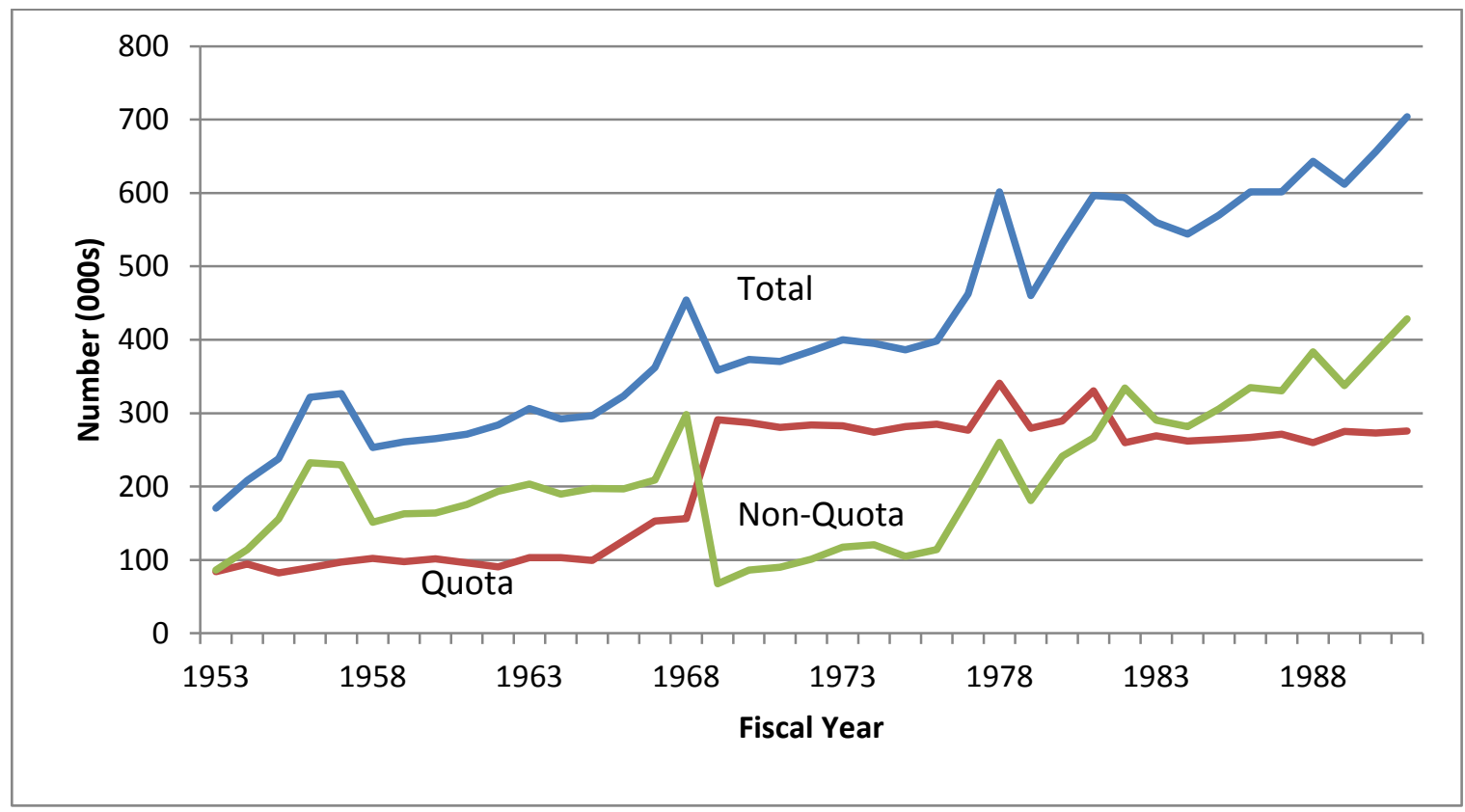

Source: Statistical Yearbook 1985 and 1991, Table IMM 1.4 and Annual Reports for 1955, 1960 and 1965 Table 4. Note: The fiscal year changed to from end June to end September in 1976; the third quarter of 1976 (reported separately in the source) has been omitted. The total excludes those admitted under the Refugee Act 1980 and legalisations in 1989-91 under the Immigration Reform and Control Act, 1986. 